\title{
SISTEMA HIDROPÔNICO COM USO DE SOLUÇÃO DE HERBICIDA NA DETECÇÃO DE SOJA GENETICAMENTE MODIFICADA RESISTENTE AO GLIFOSATO ${ }^{1}$
}

\author{
CARLAMEDIANEIRABERTAGNOLLI², MARIAÂNGELAANDRÉ TILLMANN ${ }^{3}$, FRANCISCOAMARAL VILLELA ${ }^{3}$
}

\begin{abstract}
RESUMO - Os objetivos deste estudo foram verificar a eficiência do sistema hidropônico com uso de solução herbicida na detecção de cultivares de soja GM resistentes ao glifosato e convencionais e estabelecer um protocolo de detecção em sistema hidropônico. Foram utilizadas amostras de sementes de dois genótipos geneticamente modificados e os respectivos parentais não geneticamente modificados (não-GM). Foram realizados cinco ensaios para estabelecer o protocolo de detecção; nos ensaios I e II foi realizada a pré-germinação das sementes, seguida da colocação das plântulas em recipientes contendo solução nutritiva, com posterior transferência para solução de herbicida (as concentrações utilizadas foram $0 ; 0,12 ; 0,24 ; 0,36 ; 0,48 \%$ do equivalente ácido do glifosato), e finalmente, as plântulas retornaram para a solução nutritiva. Nos ensaios III, IV e V, as sementes foram colocadas diretamente em recipientes contendo solução de herbicida e depois transferidas para solução nutritiva. Os parâmetros avaliados foram porcentagem de plântulas normais, comprimento de plântula, de raiz e de parte aérea e número de raízes secundárias. $\mathrm{O}$ sistema hidropônico permite a detecção de sementes de soja resistente ao glifosato em 5 dias, após tratamento com solução de glifosato. O protocolo de detecção de sementes de soja GM em sistema hidropônico recomendado é a permanência das sementes em contato com a solução do herbicida na concentração de $0,12 \%$ do equivalente ácido do glifosato por quatro horas, seguido da transferência das sementes para a solução nutritiva até completar cinco dias, utilizando como parâmetro de avaliação o comprimento de plântulas e a presença de raízes secundarias das plântulas de soja GM.
\end{abstract}

Termos para indexação: Glycine max, trangênicos, hidroponia

\section{HYDROPONIC SYSTEM IN THE DETECTION OF GENETICALLY MODIFIED SOYBEAN SEEDS RESISTANTTO GLYPHOSATE}

\begin{abstract}
The objectives of this work were to verify the efficiency of the hydroponic system in the detection of genetically modified (GM) soybean seeds and to establish a detection protocol in the hydroponic system. Seed samples of the two genotype were used, one genetically modified and the respective non-genetically modified (non-GM) parent. Five assays were performed to establish the detection protocol, in assays I and II the seed pre-germination was performed and later the seedlings were placed in recipients containing nutrient solution and then transferred to herbicide solution, (the concentrations used were $0 ; 0,12 ; 0,24 ; 0,36 ; 0,48 \%$ of the equivalent glyphosate acid), and finally, the seedlings were returned to the nutrient solution. In assays III, IV and $\mathrm{V}$ the seeds were placed directly in recipients containing herbicide solution and then the seeds were transferred to nutrient solution. The evaluated parameters were percentage of normal seedlings, seedling, root and hypocotyls length and number of secondary roots. The recommended protocol consisted of the seeds permanence in contact with herbicide solution to $0.12 \%$ of the equivalent glyphosate acid for four hours, followed by the transfer of the seeds to nutrient solution until completing five days, using as evaluation parameter the seedling length and the presence of
\end{abstract}

\footnotetext{
${ }^{1}$ Submetido em 03/02/2005. Aceito para publicação em 12/12/2005. Parte da tese de doutorado da primeira autora. Departamento de fitotecnia/PPG em Ciência e Tecnologia de Sementes. FAEM/ UFPel;

${ }^{2}$ Eng. Agrônoma, Dra., Universidade Federal de Pelotas. Caixa Postal 354.
}

CEP 96010-900. Pelotas - RS. carlabertagnolli@yahoo.com.br;

${ }^{3}$ Prof Adjunto, Dr., Departamento de Fitotecnia, FAEM/UFPel. Bolsista de produtividade em Pesquisa do CNPq. 
secondary roots. The hydroponics system allows the separation of GM soybean seeds resistant to glyphosate, in five days, after treatment with glyphosate solution.

Index terms: Glycine max, transgenic, hydroponics.

\section{INTRODUÇÃO}

A soja resistente ao herbicida glifosato é uma das maiores aplicações da engenharia genética na agricultura, pois representa uma nova alternativa no controle pós-emergente de plantas invasoras, a partir do uso de um herbicida de ação total (Padgette et al., 1995). A soja transgênica possibilita o uso do glifosato em pós-semeadura, que facilita o manejo das plantas daninhas, reduz despesas com tratos culturais e diminui impactos ao meio ambiente.

O cultivo e o comércio de organismos geneticamente modificados vêm crescendo significativamente em todo o mundo, no entanto, a utilização da biotecnologia na agricultura é vista de forma diferente nas distintas regiões. Variedades transformadas aprovadas em um país e usadas comumente na agricultura comercial, às vezes, são proibidas em outros países (Mumm e Walters, 2001). Isto significa que na comercialização de lotes de sementes convencionais, produzidos em países, onde as variedades geneticamente modificadas (GM) são utilizadas, para países onde as variedades transgênicas são proibidas ou controladas rigidamente, a presença adventícia de sementes de variedades GM é inevitável (Le Buanec, 2003).

Atualmente, métodos analíticos são usados, ou estão sendo desenvolvidos para a detecção de sementes de plantas GM. Os critérios levados em conta na avaliação do desempenho de cada teste são exatidão, precisão, sensibilidade, especificidade, repetibilidade das operações e reprodutibilidade dos resultados (Bertheau et al., 2002).

Os métodos baseados na PCR e em proteínas são onerosos, necessitam de equipamentos sofisticados e pessoal altamente qualificado para a realização dos testes (Della Vecchia et al.,1998). Em laboratórios de análise de sementes, são utilizados procedimentos mais simples, como o teste de resistência a herbicida conduzido junto com o teste de germinação, chamados de bioensaios (Ayala et al., 2002).

A utilização de bioensaios adapta-se satisfatoriamente para a identificação de cultivos GM, com a característica de resistência a um determinado herbicida. Diversos trabalhos foram conduzidos por: Goggi e Stahr (1997), Bevilaqua et al.
(2000), Nascimento et al. (2000), Torres et al. (2003), Cunha (2004), Funguetto et al. (2004), Tillmann e West (2004) e Miranda (2004), visando a detecção de sementes de soja resistente ao glifosato.

Nos bioensaios, a avaliação é baseada na caracterização fenotípica dos sintomas apresentados pelas plântulas e o sistema hidropônico é uma técnica também muito utilizada para observar sintomas de deficiência e toxicidez de nutrientes e substâncias fitotoxicas em plântulas (Delhaize e Ryan, 1995.). O tamanho das plântulas e a presença de raízes secundárias são parâmetros muito importantes, utilizados com sucesso na detecção de sementes de soja GM e não-GM (Goggi e Stahr, 1997; Cunha, 2004; Funguetto et al., 2004; Tillmann e West, 2004; Miranda, 2004). Portanto, o sistema hidropônico pode se constituir numa alternativa para diferenciar esses genótipos, principalmente por esta técnica minimizar possíveis danos ao sistema radicular das plântulas, facilitando a avaliação e permitindo a obtenção de resultados mais precisos (Martinez, 1997).

Os objetivos deste trabalho foram verificar a eficiência do sistema hidropônico com uso de solução de herbicida na detecção de cultivares de soja GM resistentes ao glifosato e convencionais e estabelecer um protocolo de detecção em sistema hidropônico.

\section{MATERIAL E MÉTODOS}

O trabalho foi conduzido no Laboratório de Di-Haplóides e Hidroponia da Faculdade de Agronomia "Eliseu Maciel" da Universidade Federal de Pelotas (UFPel).

Foram utilizados dois genótipos de soja geneticamente modificada (GM) para a resistência ao glifosato, CD 213 RR e CD 214 RR e os respectivos parentais não geneticamente modificados (não-GM), OC 14 e CD 201.

A caracterização inicial dos lotes consistiu na determinação do grau de umidade e teste de germinação, segundo as Regras para Análise de Sementes (Brasil, 1992). O herbicida utilizado foi o produto comercial Roundup ${ }^{\circledR}$ contendo $480 \mathrm{~g} . \mathrm{L}^{-1}$ de sal de isopropilamina $\mathrm{N}$-(fosfometil) glicina, $360 \mathrm{~g} . \mathrm{L}^{-1}$ do equivalente ácido (e.a.) de $\mathrm{N}$-(fosfometil) glicina e $648 \mathrm{~g} . \mathrm{L}^{-1}$ de ingredientes inertes. 
$\mathrm{Na}$ condução do experimento foi utilizado um sistema hidropônico constituído de vasilhas plásticas de capacidade 5,0 litros, previamente preenchidas com solução nutritiva ou com solução herbicida. Sobre as vasilhas foram adaptadas telas de barbante coladas a um isopor, de modo que funcionassem como suporte para as sementes e/ou plântulas.

As vasilhas de plástico, juntamente com as telas adaptadas foram colocadas em banho-maria, em um tanque de metal de $2,00 \times 1,50 \times 0,50 \mathrm{~m}$, cuja temperatura foi mantida a $25^{\circ} \mathrm{C}$, através de um sistema elétrico de aquecimento, e com iluminação permanente. Para suprir o meio de oxigênio necessário ao desenvolvimento do sistema radicular, as vasilhas foram ligadas a um sistema de arejamento (mangueiras conectadas a um compressor de ar). Nas vasilhas contendo solução herbicida o sistema de arejamento permaneceu desligado, a fim de evitar a formação de espuma devido aos ingredientes detergentes contidos na formulação do glifosato.

Para estabelecer o protocolo de detecção de sementes de soja resistente ao glifosato em sistema hidropônico foram realizados cinco ensaios (Tabela 1), adequando a metodologia descrita por Camargo (1981).

Em todos os ensaios, as sementes de cada genótipo foram desinfestadas em solução de hipoclorito de sódio a $20 \%$ (produto comercial) por 10 minutos e lavadas com água destilada, para retirar o excesso do produto. Nos ensaios I e II, após a desinfestação, foi realizada a pré-germinação das sementes. Nos ensaios III, IV e V, após a desinfestação as sementes foram colocadas diretamente em contato com a solução herbicida.

Pré-germinação - Nos ensaios I e II, as sementes foram colocadas para germinar em rolos de papel germitest umedecido com uma quantidade de água equivalente a 2,5 vezes o peso do papel. Logo após foram mantidas em germinador regulado a temperatura de $25^{\circ} \mathrm{C}$, período necessário para a protrusão da raiz primária. Solução nutritiva - A concentração da solução nutritiva utilizada, foi proposta por Moore et al. (1976): $\mathrm{Ca}\left(\mathrm{NO}_{3}\right)_{2} 4 \mathrm{mM} ; \mathrm{KNO}_{3}$ $4 \mathrm{mM} ;\left(\mathrm{NH}_{4}\right)_{2} \mathrm{SO}_{4} 0,435 \mathrm{mM} ; \mathrm{KH}_{2} \mathrm{PO}_{4} 0,5 \mathrm{mM} ; \mathrm{MnSO}_{4} 2 \mu \mathrm{M}$; $\mathrm{CuSO}_{4} 0,3 \mu \mathrm{M} ; \mathrm{ZnSO}_{4}, 8 \mu \mathrm{M} ; \mathrm{NaCl} 30 \mu \mathrm{M} ; \mathrm{Fe}-\mathrm{CYDTA} 10 \mu \mathrm{M}$; $\mathrm{Na}_{2} \mathrm{MoO}_{4} 0,10 \mu \mathrm{M}$ e $\mathrm{H}_{3} \mathrm{BO}_{3} 10 \mu \mathrm{M}$. O pH da solução foi previamente ajustado para 4,0 com $\mathrm{H}_{2} \mathrm{SO}_{4} 1 \mathrm{~N}$. Solução herbicida - As concentrações utilizadas nos ensaios foram estabelecidas em experimentos preliminares. As concentrações de 0,$0 ; 0,12 ; 0,24 ; 0,36 ; 0,48 \%$ do equivalente ácido $\left(360 \mathrm{~L}^{-1}\right)$ do glifosato foram utilizadas em cada ensaio.

Ensaio I - As sementes foram submetidas à prégerminação por 48 horas. A seguir as plântulas foram colocadas sobre as telas adaptadas sobre vasilhas contendo solução nutritiva, mantidas em um tanque em banho-maria. Após ficarem 24 horas em contato com solução nutritiva, as telas com as plântulas foram transferidas para vasilhas com as soluções de herbicida, onde permaneceram por mais 24 horas. Após este período, as telas retornaram para solução nutritiva, permanecendo por 72 horas. As plântulas foram avaliadas no sétimo dia após o início do ensaio.

Ensaio II - As sementes foram submetidas à prégerminação, por 24 horas. A seguir, as plântulas foram colocadas sobre as telas adaptadas sobre vasilhas contendo solução nutritiva. Após ficarem oito horas em contato com solução nutritiva, as telas com as plântulas foram transferidas para vasilhas contendo as soluções de herbicida, onde permaneceram por mais 16 horas. Após este período, as telas com as plântulas retornaram para a solução nutritiva, permanecendo por mais 120 horas. As plântulas foram avaliadas no sétimo dia após o início do ensaio.

Ensaio III - As sementes foram colocadas diretamente sobre as telas adaptadas sobre vasilhas contendo as soluções de herbicida, por oito horas. A seguir, as telas contendo as sementes foram transferidas para vasilhas contendo solução nutritiva por 136 horas, totalizando seis dias quando foram

TABELA 1. Ensaios utilizados para estabelecer o protocolo de deteç̧ão de sementes de soja resistente ao glifosato, em sistema hidropônico, período de duração (horas) de cada etapa, e tempo (dias) necessário para completar o teste.

\begin{tabular}{cccccc}
\hline Ensaios & $\begin{array}{c}\text { Pré-Germinação } \\
(\mathrm{h})\end{array}$ & $\begin{array}{c}\text { Sol. Nutritiva } \\
(\mathrm{h})\end{array}$ & $\begin{array}{c}\text { Sol.Herbicida } \\
(\mathrm{h})\end{array}$ & $\begin{array}{c}\text { Sol. Nutritiva } \\
(\mathrm{h})\end{array}$ & $\begin{array}{c}\text { Tempo } \\
(\text { dias})\end{array}$ \\
\hline I & 48 & 24 & 24 & 72 & 7 \\
II & 24 & 8 & 16 & 120 & 7 \\
III & - & - & 8 & 136 & 6 \\
IV & - & - & 4 & 116 & 5 \\
V & - & - & 1 & 119 & 5 \\
\hline
\end{tabular}

${ }^{1} 0,0 ; 0,12 ; 0,24 ; 0,36 ; 0,48 \%$ do equivalente ácido do glifosato utilizadas em cada ensaio. 
realizadas as avaliações.

Ensaio IV - As sementes foram colocadas diretamente sobre as telas adaptadas sobre vasilhas contendo as soluções de herbicida, por quatro horas. A seguir, as telas contendo as sementes foram transferidas para vasilhas contendo solução nutritiva, por 116 horas, totalizando cinco dias quando foram realizadas as avaliações.

Ensaio V - As sementes foram colocadas diretamente sobre as telas adaptadas sobre vasilhas contendo solução herbicida, por uma hora. A seguir, as telas contendo as sementes foram transferidas para vasilhas contendo as soluções nutritiva por 119 horas, totalizando cinco dias, quando foram realizadas as avaliações.

Avaliações - Os parâmetros avaliados foram porcentagem de plântulas normais, comprimento total de plântula, da raiz primária e da parte aérea, além do número de raízes secundárias. Foram consideradas plântulas normais àquelas que apresentavam comprimento total mínimo de 3 $\mathrm{cm}$ e presença de raízes secundárias desenvolvidas. As médias da germinação foram expressas em porcentagem. O comprimento das plântulas foi medido com o auxílio de uma régua de escala centimetrada, e os resultados expressos em centímetros.

Procedimento estatístico - Os resultados foram analisados segundo o delineamento inteiramente casualizado com três repetições de 50 sementes. Os dados médios das avaliações foram apresentados graficamente. Na execução das análises foi utilizado o Sistema de análise estatística para Windows - WinStat Versão 2.0 (Machado e Conceição, 2003).

\section{RESULTADOS E DISCUSSÃO}

Ensaios para seleção do protocolo de detecção de sementes de soja GM

Para a seleção do protocolo de detecção de sementes de soja GM foram avaliados os parâmetros germinação, comprimento total de plântula, da parte aérea e de raiz primária e número de raízes secundárias.

Os resultados de germinação obtidos nos ensaios I, II, III e IV indicaram que o cultivo hidropônico permite a detecção de sementes de soja resistente ao glifosato, empregando-se as concentrações de solução de herbicida testadas (Figura 1).

As sementes das cultivares CD 214 RR e CD 213 RR resistentes ao glifosato, após permanecerem em contato com a solução de herbicida, inclusive na mais alta concentração, produziram plântulas normais bem desenvolvidas e apresentaram raízes secundárias.
Por outro lado, verificou-se que mesmo a menor concentração da solução de herbicida utilizada foi capaz de inibir parcialmente a germinação das sementes das cultivares não-GM (OC 14 e CD 201), que apenas iniciaram o processo germinativo não atingindo comprimento suficiente para que fossem consideradas plântulas normais.

As sementes das cultivares GM contêm o gene CP4EPSPS, oriundo da bactéria Agrobacterium sp cepa CP4, que confere resistência ao herbicida por codificar uma variante da enzima EPSPS insensível a este inibidor, permitindo o desenvolvimento de plântulas normais (Padgette et al., 1995; Dellanay et al, 1995; Elmore et al., 2001).

$\mathrm{O}$ ensaio $\mathrm{V}$ não permitiu a separação das cultivares GM das não-GM (Figura 1). As plântulas não-GM foram consideradas normais, apresentaram-se bem desenvolvidas e com raízes secundárias. Neste ensaio as sementes testadas ficaram em contato com a solução herbicida somente durante uma hora correspondendo à parte da fase I do processo de germinação (Bewley e Black, 1994). Mesmo na presença da concentração mais alta, $0,48 \%$ do e.a. do glifosato, as sementes de soja não-GM não foram afetadas pela ação do herbicida. Este resultado indica que, possivelmente o tempo de contato da semente com a solução herbicida foi insuficiente para a ação do produto. Utilizando imersão de sementes de soja em solução herbicida, por período de uma hora, mesmo utilizando solução em alta concentração, Funguetto et al. (2004) também não conseguiram separar sementes de soja GM das não-GM. Entretanto, Tillmann e West (2004) relataram que a imersão das sementes de soja por uma hora a uma temperatura de $30^{\circ} \mathrm{C}$, permitiu diferenciar as cultivares GM das não-GM, em todas as concentrações de glifosato estudadas. As plântulas de soja GM foram resistentes a todas as concentrações de herbicida, apesar destas cultivares apresentarem redução no tamanho das plântulas. É importante salientar que neste caso as sementes foram submetidas a estresse de temperatura na embebição, o que possivelmente pode ter incrementado o efeito fitotóxico do herbicida.

Na Figura 1, observa-se ainda que, exceto no ensaio V, todas as concentrações testadas foram suficientes para que as sementes de soja não-GM produzissem plântulas anormais, permitindo, desta maneira a diferenciação das cultivares. A formulação da solução herbicida utilizada nos bioensaios é uma das principais questões na execução deste tipo de teste. A concentração da solução herbicida utilizada nos bioensaios segundo Gutormson (2000), deve permitir a plântula nãoGM expressar sintomas de toxicidade: inibição do desenvolvimento da raiz primária e da emissão de raízes 
(l)
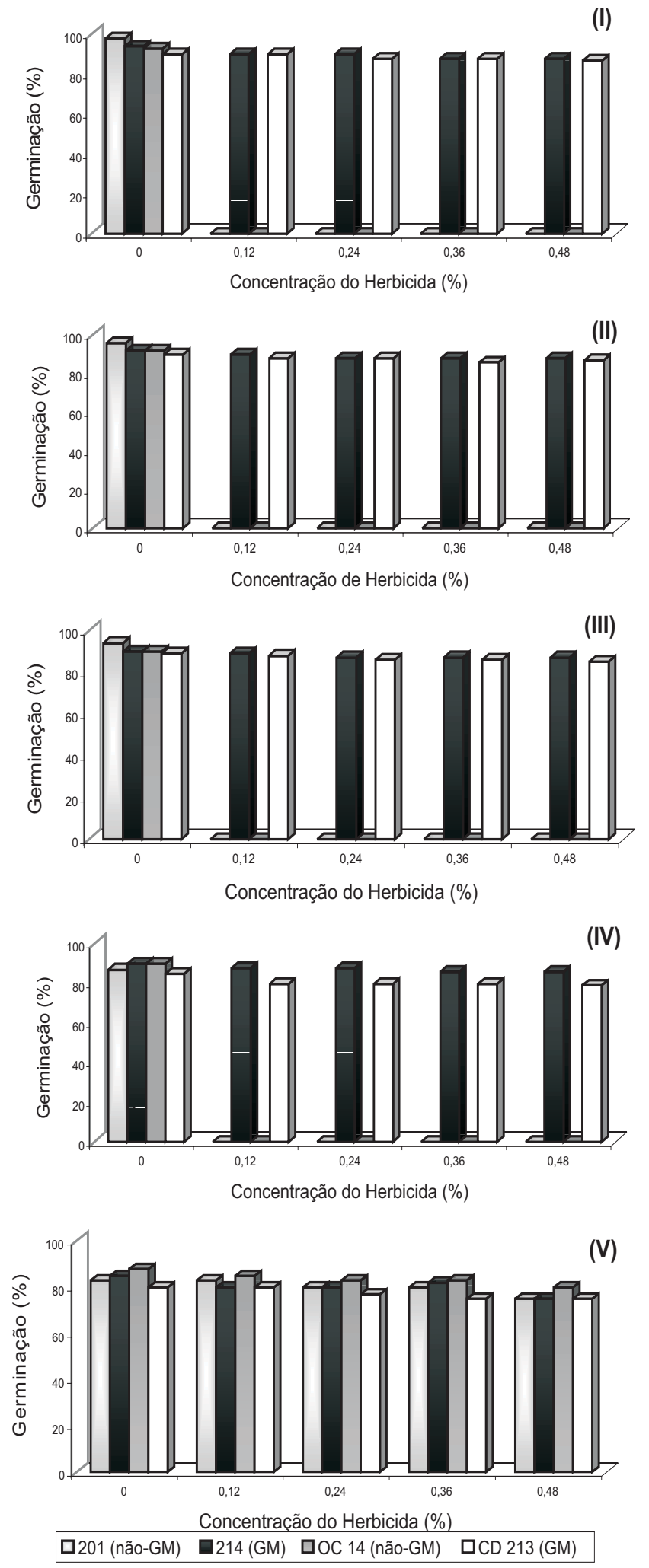

FIGURA 1. Porcentagens de germinação de sementes de soja GM e não-GM, obtidas nos ensaios (I), (II), (III), (IV) e(V) utilizando diferentes concentrações de solução herbicida em sistema hidropônico. secundárias, além de reduzir o comprimento do hipocótilo, conforme constatado por Goggi e Stahr, (1997), Tillmann e West (2004) e Funguetto et al. (2004).

Vários autores estudaram a utilização dos bioensaios na detecção de sementes de soja resistente ao glifosato, utilizando diferentes procedimentos de condução. Goggi e Stahr (1997), Torres et al. (2003), Tillmann e West (2004), Funguetto et al. (2004), Cunha (2004) e Miranda (2004) observaram que os métodos baseados na germinação das sementes, em meio contendo solução herbicida foram eficientes na detecção de soja transgênica, independentemente da metodologia utilizada. Os resultados obtidos neste trabalho concordam com os alcançados pelos autores citados e evidenciam a eficiência do sistema hidropônico com uso de solução de herbicida, como um procedimento alternativo na detecção de soja transgênica.

O sistema hidropônico foi utilizado por Siqueira et al. (1998) para avaliar graus de tolerância ao glifosato de diversos genótipos de soja, através do cultivo de explantes, o qual mostrou-se adequado para testar o efeito do glifosato em sementes de soja, em razão da rapidez na obtenção de resultados finais e, devido a sua grande reprodutibilidade.

Vale destacar que um dos critérios levados em conta na avaliação do desempenho dos testes para detecção de sementes de organismos GM é a reprodutibilidade dos resultados e tempo de execução (Bertheau et al., 2002).

Uma das principais limitações dos bioensaios é o tempo necessário para a alcançar os resultados (Lübeck, 2004), que geralmente é de sete dias. Baseado neste fato, elegeu-se o ensaio IV, como o protocolo de deteç̧ão de sementes de soja resistente ao glifosato em sistema hidropônico. No ensaio IV, as sementes ficaram em contato com a solução herbicida durante quatro horas e no quinto dia após o inicio do teste foi possível à diferenciação das cultivares GM e não-GM.

Os outros parâmetros avaliados comprimento total de plântula, da parte aérea e de raiz primária e número de raízes secundárias apresentaram comportamento semelhante nos ensaios I, II, III e IV. Baseado nesta informação foram apresentados neste artigo os dados referentes ao Ensaio IV.

\section{Detecção de sementes de soja GM em sistema hidropônico}

Porcentagem de germinação: Os quatro genótipos apresentaram um percentual de plântulas normais igual ou superior a $80 \%$ quando foi utilizada a concentração zero de herbicida (Figura 1), confirmando a similaridade quanto à germinação entre as sementes de soja GM e não-GM. Os lotes apresentaram graus de umidade similares, entre 12,8 e 
13,1\%, o que permitiu inferir que este parâmetro não interferiu nos parâmetros avaliados.

As sementes das cultivares não-GM iniciaram o processo de germinação quando expostas as diferentes concentrações de herbicida, no entanto a ação do herbicida inibiu o desenvolvimento de plântulas normais destas cultivares. Da mesma forma, Duke e Hoagland (1981) relataram que na presença de glifosato, sementes de soja não-GM iniciaram o processo de germinação, mas subseqüentemente o desenvolvimento tornou-se insignificante até parar completamente, produzindo plântulas anormais.

As cultivares GM apresentaram alta porcentagem de germinação, mesmo na mais alta concentração utilizada $(0,48 \%)$. Resultados semelhantes foram observados por Goggi e Stahr (1997) ao testarem sementes de soja GM préembebidas em solução de Roundup por $18 \mathrm{~h}$. Os autores constataram que após sete dias, as plântulas oriundas de sementes de soja GM, apresentavam-se completamente desenvolvidas e foram classificadas como normais. Em estudos com soja transgênica pré-embebida em solução com herbicida, Tillmann e West (2004), também encontraram que a germinação das sementes de soja GM não foi reduzida até a concentração de 1,5\% do e a (equivalente ácido) do glifosato. Outros autores como Bevilaqua et al. (2000); Torres et al. (2003), Cunha (2004), Funguetto et al. (2004) e Miranda 2004, também constataram que a porcentagem de germinação das sementes de soja resistente ao glifosato não foi afetada pela exposição à solução de herbicida, possibilitando desta maneira a separação de genótipos GM de não-GM.

O cultivo hidropônico, com o uso de solução de herbicida, mostrou-se um método eficiente na detecção de sementes de soja das cultivares GM e das não-GM, utilizando como parâmetro a porcentagem de germinação.

Comprimento de plântulas- Em relação ao comprimento total das plântulas (Figura 2), pode-se afirmar que o herbicida afeta negativamente o crescimento das plântulas das cultivares não-GM (OC-14 e CD 201) de maneira mais significante que o crescimento das plântulas GM (CD 213 RR e CD 214 RR).

O decréscimo no tamanho das plântulas normais das cultivares resistente ao glifosato ocorreu proporcionalmente ao aumento da concentração da solução herbicida. Esses dados concordam com relatos de Tillmann e West (2004) e Funguetto et al. (2004), que verificaram redução do comprimento total de plântulas de soja da cultivar GM tratadas com glifosato em relação à testemunha.

Independentemente da concentração de herbicida

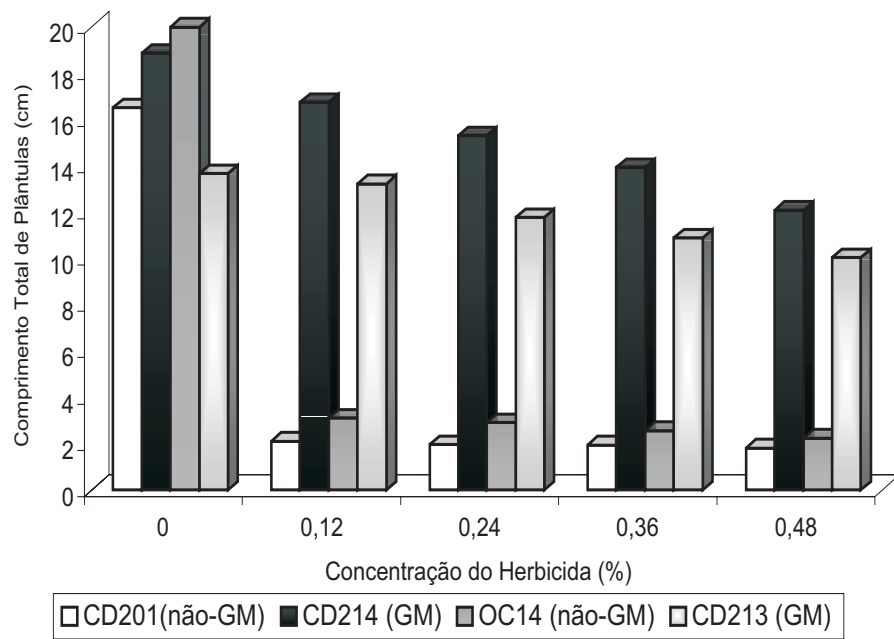

FIGURA 2. Comprimento total de plântulas de soja GM e nãoGM, após quatro horas em contato com solução contendo diferentes concentrações de herbicida, em sistema hidropônico.

utilizada, as plântulas das cultivares convencionais tiveram acentuada redução no comprimento total, se comparadas com as submetidas à concentração zero. A redução no comprimento pode ser atribuída a privação de aminoácidos aromáticos, provocada pelo glifosato, que compromete a biossíntese de enzimas envolvidas na produção de carboidratos e lipídeos (Siqueira et al., 1998).

Apesar do herbicida causar redução no crescimento das plântulas de todos os genótipos estudados, foi possível separar as cultivares GM das convencionais, utilizando como parâmetro o comprimento total de plântulas. Ao compararem plantas transformadas que possuíam o gene de resistência ao glifosato com plantas não transformadas, Daniell et al. (1998), observaram que as plantas controle (não-GM) eram extremamente sensíveis ao glifosato, enquanto as plantas transgênicas sobreviveram a altas concentrações do herbicida.

Uma evidente distinção entre o comprimento de parte aérea das plântulas de soja GM e não GM foi verificada em todas as concentrações utilizadas devido à ação do glifosato, como se observa na Figura 3. As cultivares CD 212 RR E CD 213 RR suportam concentrações do herbicida, que são letais a genótipos não-GM. Estes dados concordam com resultados obtidos por Siqueira et al. (1999) em estudo que simulou soja resistente ao glifosato por meio de cultivo de explantes em sistema hidropônico. Estes autores relataram que os tratamentos com glifosato reduziram a massa seca e o comprimento da parte aérea de plântulas de soja. No entanto, os explantes que receberam aminoácidos aromáticos via 


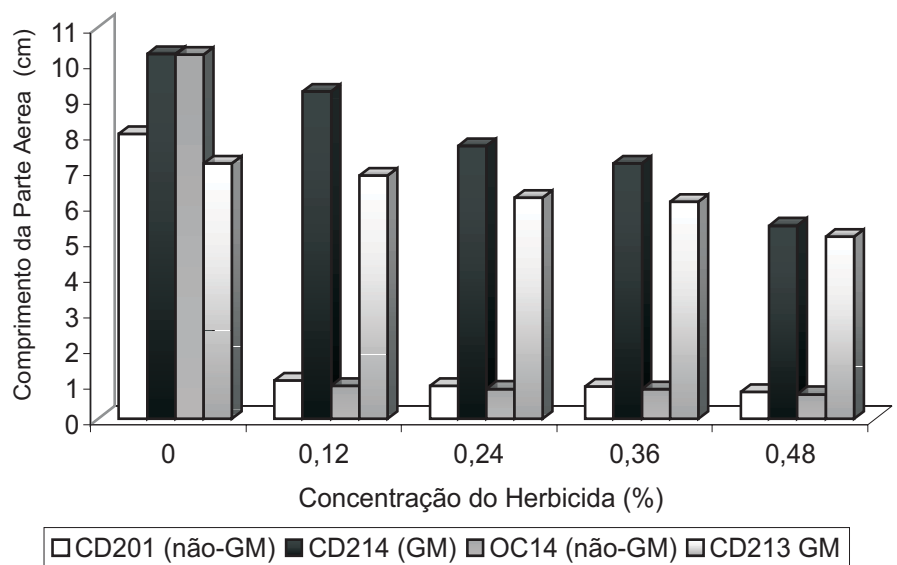

FIGURA 3. Comprimento de parte aérea de plântulas de soja GM e não-GM, após quatro horas em contato com solução contendo diferentes concentrações de herbicida, em sistema hidropônico

solução nutritiva, não apresentaram sintomas visuais típicos de fitotoxicidade, a massa seca e comprimento de parte aérea das plântulas não foi reduzido, tanto quanto seus constituintes bioquímicos não foram afetados.

O comprimento da raiz primária tem sido utilizado com sucesso na diferenciação fenotípica de cultivares de soja resistentes e suscetíveis ao glifosato (Goggi e Sthar, 1997; Tillmann e West, 2004; Cunha, 2004; Funguetto et al., 2004). Na Figura 4, observa-se que as plântulas das cultivares de soja não-GM apresentaram uma redução drástica no comprimento de raiz primária quando foram expostas às diferentes concentrações de herbicida, se comparadas com as submetidas à concentração zero. Tal fato pode ser explicado pela interrupção do processo de mitose e ruptura dos plastídios, como efeito indireto e secundário do glifosato, que desta maneira reduz a matéria seca das plântulas (Mousdale e Coggins, 1991).

Em relação ao comprimento das plântulas, Funguetto et al. (2004) e Cunha (2004) relataram que a redução no sistema radicular das plântulas não-GM foi mais drástica do que a do comprimento da parte aérea, ao utilizarem em seus ensaios a metodologia do substrato de papel umedecido com solução herbicida. No presente trabalho, o herbicida afetou o comprimento da parte aérea e da raiz primária de forma semelhante nos genótipos avaliados (Figuras 3 e 4). Este efeito pode ser atribuído ao cultivo hidropônico, que possivelmente produziu efeitos mais drásticos de fitotoxicidade nos genótipos não-GM, já que as plântulas provenientes de sementes de soja não-GM apresentaram um comprimento total máximo de três centímetros.

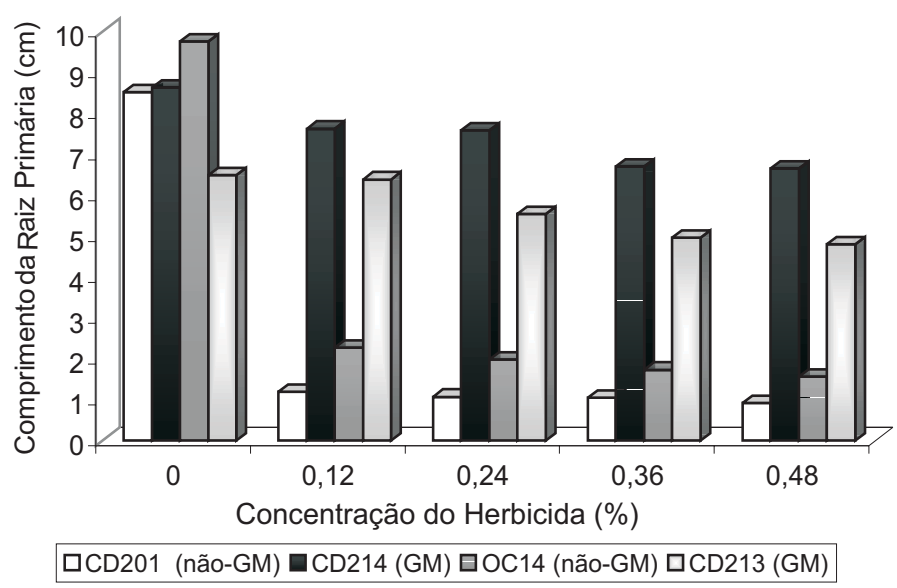

FIGURA 4. Comprimento de raiz primária de plântulas de soja GM e não-GM, após quatro horas em contato com solução contendo diferentes concentrações de herbicida, em sistema hidropônico.

Um fator que, provavelmente, agravou o quadro de fitotoxicidade das plântulas de soja não-GM decorre do incremento da eficiência do glifosato com o aumento da disponibilidade hídrica (Kruse et al., 2000). Segundo estes autores, a maior intensidade luminosa favorece a translocação do herbicida. Pelo fato de no sistema hidropônico as plântulas permanecem em um ambiente com alta disponbilidade de água e pernamentemente na presença de luz, é possível que estas condições tenham potencializado a ação do glifosato sobre as plântulas que não apresentam resistência ao herbicida.

De acordo com as proposições de Cobb (1992) para relações água-planta, no que se refere à absorção de herbicida, o potencial hídrico negativo da solução nutritiva em que são cultivadas as plântulas, eleva-se progressivamente da raiz em direção à parte aérea. A diferença entre os potenciais hídricos dos tecidos das plântulas e da solução nutritiva determina o influxo da mesma e de seus solutos pelo xilema, e segundo Siqueira et al. (1998), a ação rápida do glifosato ocorre devido a sua fácil absorção pelo xilema e rápida translocação.

Desta maneira, o comprimento de plântulas foi um parâmetro adequado para diferenciar cultivares de soja GM dos não-GM, através da análise visual do tamanho das plântulas. Foram observadas diferenças marcantes entre as plântulas resistentes ao glifosato e as sensíveis, com destaque para as plântulas resistentes que, na presença de baixa concentração de herbicida $(0,12 \%)$, apresentaram comprimento de raiz primária e parte aérea semelhantes ao das plântulas submetidas à concentração zero, conforme mostram as Figuras 2, 3 e 4.

Número de raízes secundárias- $\mathrm{O}$ número de raízes 
secundárias foi uma adequada característica morfológica utilizada para distinguir as cultivares de soja GM das não-GM (Figura 5). Os genótipos não resistentes ao glifosato mostraram ausência total de raízes secundárias, enquanto as plântulas de soja GM apresentaram, em todas as concentrações raízes secundárias abundantes e bem desenvolvidas.

Vários autores (Goggi e Stahr, 1997; Nascimento et al., 2000; Bevilaqua at al., 2000; Tillmann e West, 2004; Funguetto et al., 2004, Cunha 2004), avaliando métodos para identificação de soja resistente ao glifosato, concordam que este parâmetro foi fundamental na separação dos genótipos GM e convencionais. Ao utilizaram bioensaios na seleção de

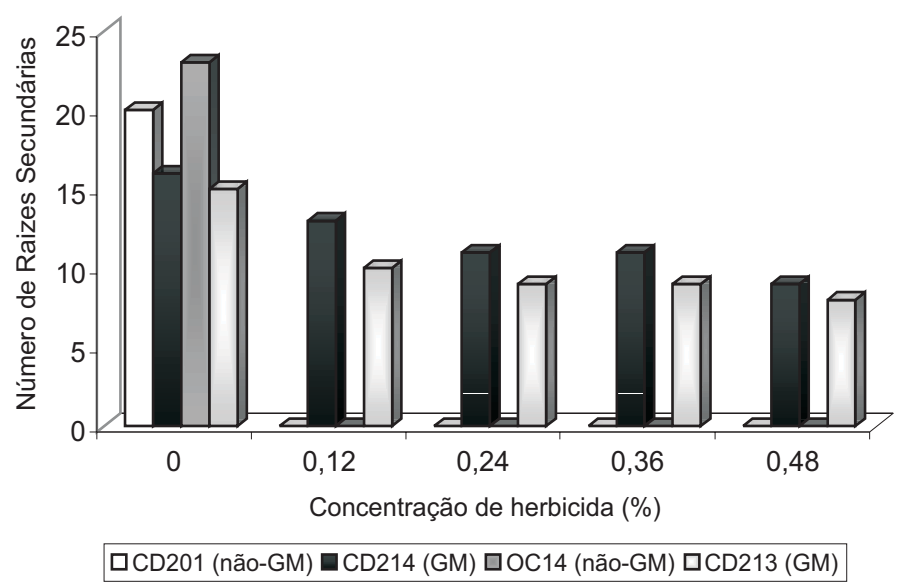

FIGURA 5. Número de raízes secundárias de plântulas de soja GM e não-GM, após quatro horas em contato com solução contendo diferentes concentrações de herbicida, em sistema hidropônico. genótipos de canola GM tolerante a phosphinothricin, Pfeilstetter et al. (2000) detectaram uma clara diferenciação entre plântulas sensíveis e tolerantes ao herbicida, onde as plântulas GM apresentaram-se bem desenvolvidas e com raízes secundárias.

O número de raízes secundárias é a característica que mais se destacou na identificação de plântulas originárias de sementes de soja GM.

Conforme os resultados obtidos, utilizando a metodologia do sistema hidropônico pode-se distinguir as cultivares de soja GM das não-GM, cinco dias após o início da execução do teste. Embora todas as concentrações testadas tenham se mostrado eficientes, como é possível observar nas Figuras $1,2,3,4$ e 5 , a concentração de $0,12 \%$ é a mais recomendada. Os parâmetros que melhor permitiram separar as cultivares foram comprimento de plântula e presença de raízes secundárias das plântulas das cultivares GM (Figura 6).

Utilizando o sistema hidropônico com uso de solução herbicida foi possível observar os sintomas provocados pelo glifosato nas plântulas, no quinto dia após o inicio do teste.

Os sintomas causados pelo herbicida podem ser observados nas Figuras 7 e 8, as plântulas de soja não-GM apresentaram limitação no desenvolvimento da parte aérea e da raiz primária. Além disso, o glifosato afetou a emissão de raízes secundárias. Esses dados concordam com os relatados por Funguetto et al., (2004) que, ao empregar em bioensaios para caracterizar as cultivares GM e não-GM, observaram que o glifosato causa anormalidade em plântulas de soja nãoGM, caracterizada por inibição do desenvolvimento da raiz

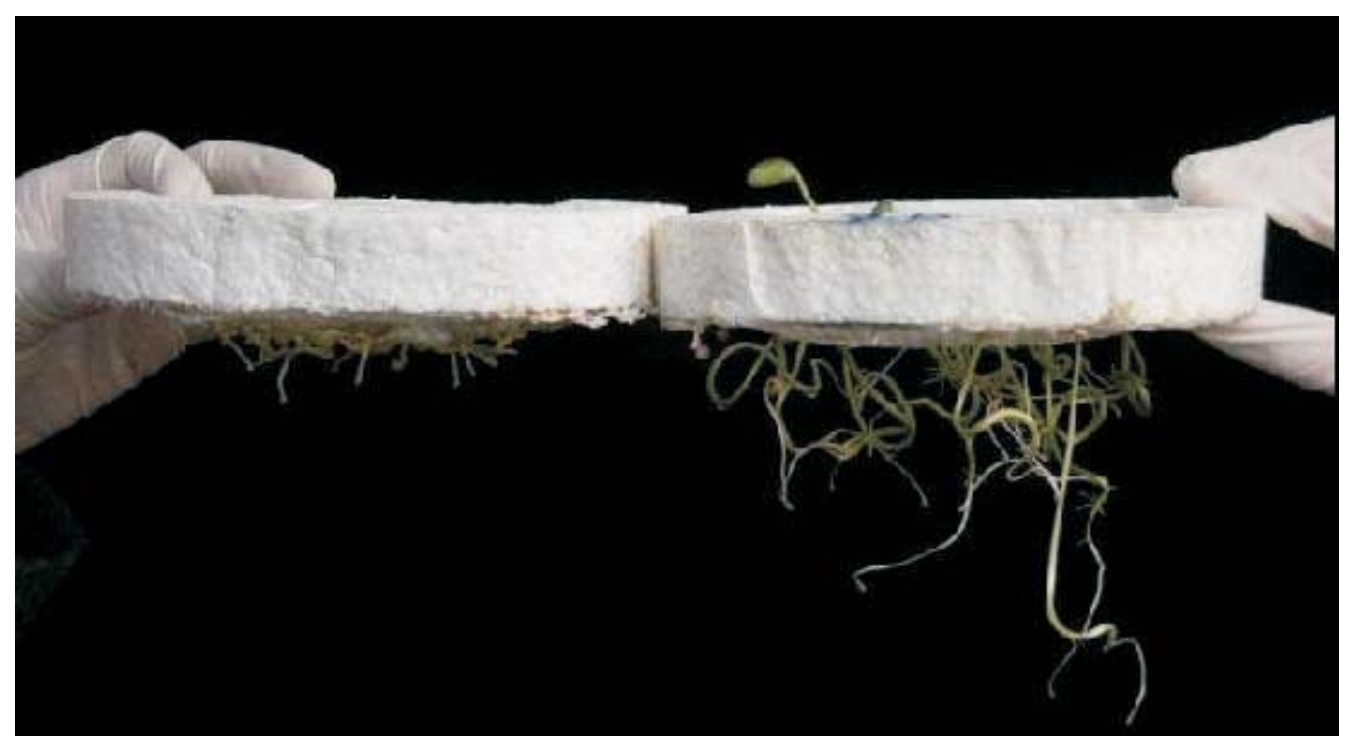

FIGURA 6. Plântulas de soja GM e não-GM, obtidas em sistema hidropônico, após quatro horas em contato com solução de $0,12 \%$ do glifosato. 


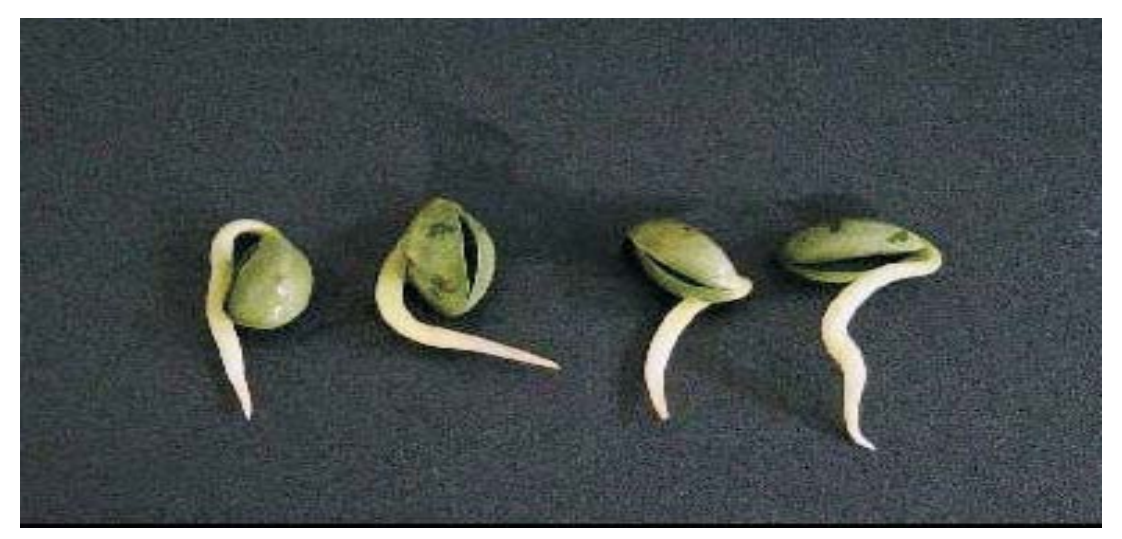

FIGURA 7. Características morfológicas em plântulas de soja não-GM submetidas à solução de $0,12 \%$ de glifosato em sistema hidropônico.

primária e da emissão de raízes secundárias, engrossamento e amarelecimento gradativo do hipocótilo.

Esta limitação no comprimento das plântulas é resultado da ação do herbicida que inibe a enzima EPSPS, impedindo que a planta produza aminoácidos aromáticos essenciais para a síntese de proteínas e alguns metabólitos secundários (Padgette et al., 1995).

Ao testar graus de tolerância ao glifosato em explantes de genótipos de soja, em cultivo hidropônico, Siqueira et al. (1998) observaram que os sintomas visuais típicos de fitotoxicidade por glifosato surgiram após o terceiro dia de aplicação do herbicida. No presente estudo pode-se inferir que antes da ação efetiva do herbicida, as sementes iniciaram o processo germinativo, deste modo, as características que permitem separar os genótipos GM e não-GM puderam ser caracterizadas com segurança somente no quinto dia, após o inicio do teste.

O glifosato também afetou a emissão de raízes secundárias nas plântulas de soja não-GM, o que pode ser explicado pelo fato de que o glifosato provoca o déficit de aminoácidos aromáticos e compostos fenólicos secundários, tendo como conseqüência efeito inibitório na organogênese, impedindo a diferenciação das raízes (Nagata et al., 2000).

Outra característica marcante das plântulas de soja nãoGM após contato com a solução de herbicida, em sistema hidropônico, foi a aparência das raízes primárias que se apresentavam afinadas, lisas e firmes (Figura 7). Esta característica morfológica foi importante e muito utilizada na separação dos genótipos avaliados. Gutormson (2000) relata que um dos sintomas típicos que as plântulas de soja nãoGM apresentam, quando submetidas aos bioensaios são raízes primárias pequenas e firmes.

A solução de glifosato não produziu efeito sobre as sementes de soja GM, que mesmo na presença de herbicida produziram plântulas normais, bem desenvolvidas e com raízes secundárias abundantes (Figura 8). Após o tratamento com glifosato, a plântula de soja GM permanece inalterada, pois a ação continuada da enzima CP4-EPSPS permite que a plântula continue produzindo aminoácidos aromáticos, não comprometendo a biossíntese de enzimas envolvidas na

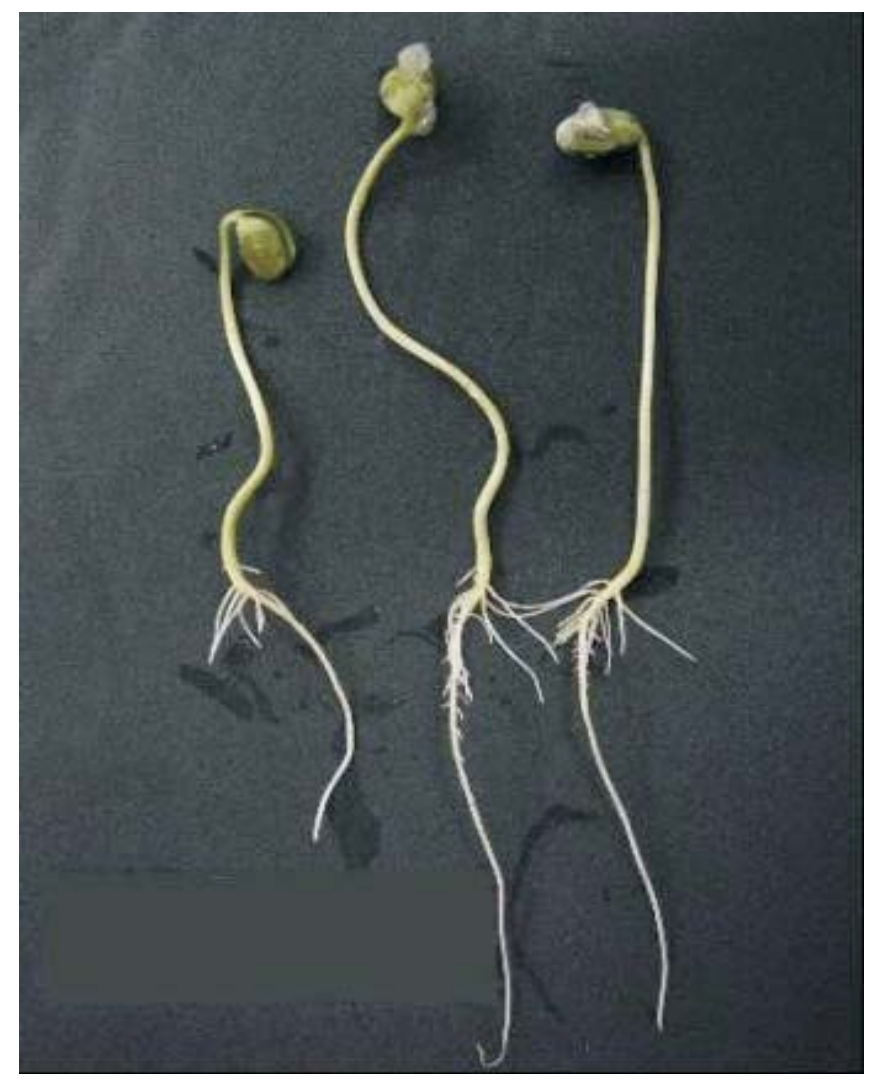

FIGURA 8. Características morfológicas em plântulas de soja GM submetidas à solução de $0,12 \%$ de glifosato, em sistema hidropônico. 
produção de carboidratos e lipídeos (King et al., 2001), essenciais ao crescimento e desenvolvimento das plântulas.

Os genótipos de soja GM podem apresentar plântulas anormais, não devido à ação do herbicida, mas a danos mecânicos ou lesão no tecido de condução. Na presente pesquisa, as plântulas anormais GM puderam ser caracterizadas pela presença das raízes secundárias. Da mesma forma, em estudos com soja GM, Cunha (2004) indicou que a presença de raízes secundárias é a característica que torna possível diferenciar as plântulas de soja não-GM das anormais GM.

O sistema hidropônico com uso de solução herbicida mostrou-se eficiente na caracterização dos sintomas provocados pelo glifosato nas plântulas de soja GM e nãoGM em cinco dias, principalmente por esta metodologia minimizar possíveis danos no sistema radicular das plântulas, facilitando a avaliação e permitindo a obtenção de resultados mais precisos.

Os parâmetros que permitem a diferenciação das cultivares são comprimento de plântula e presença de raízes secundárias das plântulas GM e a raiz primaria das plântulas não GM que apresentam-se pequenas e firmes.

\section{CONCLUSÕES}

Em sistema hidropônico é possível a detecção de sementes de soja resistente ao glifosato em cinco dias, após tratamento com solução de glifosato.

O protocolo recomendado de detecção de sementes de soja GM em sistema hidropônico é a permanência das sementes em contato com a solução do herbicida na concentração de $0,12 \%$ do equivalente ácido do glifosato por quatro horas, seguido da transferência das sementes para a solução nutritiva até completar cinco dias, utilizando como parâmetros de avaliação o comprimento de plântulas e a presença de raízes secundárias das plântulas de soja GM.

O glifosato causa anormalidade em plântulas de soja nãoGM, ocasionando a formação de raízes afinadas, lisas e firmes; redução no comprimento de raiz primária e parte aérea e inibição da emissão de raízes secundárias, enquanto as plântulas de soja GM apresentam raiz primária e parte aérea bem desenvolvidas e raízes secundárias abundantes.

\section{REFERÊNCIAS}

AYALA, L.; TILLMANN; M.A.A.; DODE, L.B.; VILLELA, F.A.; MAGALHÃES, A.M.; SILVA, M.P. Tetrazolium test for identificatin of transgenic rice seeds tolerant to herbicide. Seed
Science and Technology, Zürich, v.30, p.431-436, 2002.

BERTHEAU, Y.; DIOLEZ, A.; KOBILINSKY, A.; MAGIN, K. Detection methods and performance criteria for genetically modified organisms. Journal of AOAC International, Maryland, v.85, n.3, p.801-808, 2002.

BEVILAQUA, G.A.P.; BONATO, E.R.; ROMAN, E.S. Identificação de soja tolerante a glyphosate através do teste de germinação. Revista Brasileira de Herbicidas, Brasília, v.1, n.3, p.261-265, 2000.

BEWLEY, J.D.; BLACK, M. Seeds: physiology of development and germination. 2ed. New York: Plenum Press, 1994, 445p.

BRASIL. Ministério da Agricultura e Reforma Agrária. Regras para análise de sementes. Brasília:SNDA/DNDV/CLAV, 1992.365p.

CAMARGO, C.E.O. Melhoramento do trigo. I. hereditariedade da tolerância do alumínio tóxico. Bragantia, Campinas, v.40, p. 33 45, 1981.

COBB, A. Herbicides and plant physiology. London: Champaman and Hall, 1992, 176.p.

CUNHA, C.S.M. Comparação de métodos na detecção de sementes de soja geneticamente modificada, tolerante ao glifosato. 2004. 24f. Dissertação (Mestrado em Ciência e Tecnologia de Sementes) - Faculdade de Agronomia "Eliseu Maciel", Universidade Federal de Pelotas, Pelotas, 2004.

DANIELL, H.; DATTA, R.; VARMA, S.; GRAY, S.; LEE, S.B. Containment of herbicide resistance through genetic engineering of the cloroplast genome. Nature Biotechnology, New York, v.16, p.343-348, 1998.

DELANNAY, X. et al. Yield evaluation of a glyphosate-tolerant soybean lineafter treatment with glyphosate. Crop Science, Madison, v.35, p. 1461-1467, 1995.

DELHAIZE, E.; RYAN, P.R. Aluminum toxicity and tolerance in plants. Plant Physiology, Rockville, v.107, n.2, p.315-321, 1995.

DELLA VECCHIA, P.T.; SILVA, C.A.R.; TERENCIANOSOBRINHO, P. Use of molecular marker techniques in seed testing by brazilian seed companies. Scientia Agricola, Piracicaba, v.55, p.79-81, 1998.

DUKE, S.O.; HOAGLAND, R.E. Effects of glyphasate on metabolism of phenolic compounds. Phenylalanine ammonialyase activity, free amino acids Root-fed amino acids and glyphosate toxicity in soybean (Glycine max) seedlings. Weed Science, Champaign, v.29, p.297, 1981.

ELMORE, R.W.; ROETH, F.W.; KLEIN, R.N.; KNEZEVIC, S.Z.; MARTIN, A.; NELSON, L.A.; SHAPIRO, C.A. GlyphosateResistant soybean cultivar response to glyphosate. Agronomy Journal, Madison, v.93, p. 404-407, 2001.

FUNGUETTO, C.I.; TILLMANN, M.A.A.; VILLELA, F.A.; DODE, L.B. Detecção de sementes de soja geneticamente modificada tolerante ao herbicida glifosato. Revista Brasileira de Sementes, Pelotas, v.26, n.1,p.130-138, 2004.

GOGGI, A.S.; STAHR, M.G. Roundup ${ }^{\circledR}$ pre-emergene treatment to determine the presence of the Roundup ${ }^{\circledR}$ gene in soybean seeds: a laboratory test. Seed Technology, Kentucky, v.19, n.1, p.99$102,1997$.

GUTORMSON, T; BRIX-DAVIS, K.; JAUERT, P. A Comparison of 
GMO testing strategies. Seed World, Illinois, v.138, p.10-12, 2000.

GUTORMSON, T. Herbicide trait testing IN: MCDONALD, M.B.; GUTORMSON, T.TURNIPSEED, B. (Ed). Seed technologist training manual. Society of Commercial Seed Technologists, 2000. 292 p.

KRUSE, N.D.; TREZZI, M.N.; VIDAL, R.R. Herbicidas inibidores da EPSPS: revisão de literatura. Revista Brasileira de Herbicidas, Brasília, v.1, n.2, p. 139-146, 2000.

LE BUANEC, B. Genetically modified varieties and the seed industry. ISTA News Bulletin, Zürich, n.125, p.10, 2003.

LÜBECK M. Detection of genetically modified plants -methods to sample and analyze GMO contend in plants and plant products. Disponível em <http://www.sns.dk/erhvogadm/biotek/ detection.htm>. Acesso em: 17 out. 2004.

MACHADO, A.A.; CONCEIÇÃO, A.R. Sistema de análise estatística para Windows. WinStat. Versão 2.0. Pelotas: UFPel, 2003.

MARTINEZ, H.E.P. O uso do cultivo hidropônico de plantas em pesquisa. Cadernos Didáticos.Viçosa, n.1, p.10-15, 1997.

MIRANDA, D.M. Bioensaios na detecção e quantificação de sementes de soja geneticamente modificada resistente ao glifosato em amostras convencionais de sementes. 2004. 44f. Dissertação (Mestrado em Ciência e Tecnologia de Sementes) Faculdade de Agronomia "Eliseu Maciel", Universidade Federal de Pelotas, Pelotas, 2004.

MOORE, D.P.; KRONSTAD, W.E.; METZGER, R.J. Screening wheat for aluminum tolerance. In: WORKSHOP ON PLANT ADAPTATION TO MINERAL STRESS IN PROBLEM SOILS, 1976, Beltsville. Proceedings. Ithaca: Cornell University, 1976, p.287-295.

MOUSDALE D.M.; COGGINS J.R. Amino Acid Sinthesis In: KIRKWOOD, R.C. (Ed.) Target sites for herbicide action. London: Plenum Press, 1991, p. 29-39.
MUMM, R.H.; WALTERS, D.S. Quality control in development of transgenicas crop seed products. Crop Science, Madison, v.41, p.1381-1389, 2001.

NASCIMENTO, W.N.; TORRES, A.C.; FERREIRA, A.T.; PAIVA, S.A.V. Bioensaio para detecção de plantas transgênicas de soja tolerante ao herbicida glifosato. In: SEMINÁRIO PANAMERICANO DE SEMILLAS, 17., 2001, Punta Del Este. Anais... Punta del Este: FELAS, v.1, 2000, p.102.

PADGETTE, S.R.; KOLACZ, K. H.; DELANNAY, X.; RE, D.B.; LA VALLEE, D.J.; TINIUS, C.N.; RHODES, W.K.; OTERO, I.; BARRY, G.F. Development, identification and characterization of a glyphosate-tolerant soybean line. Crop Science, Madison, v.35, p.1451-1461, 1995.

PFEILSTETTER, E.; MATZK, A.; FELDMANN, S.D.; SCHIEMANN, J. Rapid and efficient screening of phosphinothricin tolerant oilseed rape (Brassica napus) whit a novel germination test. Euphityca, Dordrecht, p.119-124, 2000.

SIQUEIRA, S.C.; MOREIRA, M.A.; MOSQUIM, P.R. Supressão fisiológica dos efeitos fitotóxicos do glifosato em explantes de soja. Revista Brasileira de Fisiologia Vegetal, Campinas, v.10, n.2, p.137-142, 1998.

SIQUEIRA, S.C.; MOREIRA, M.A.; MOSQUIM, P.R.; JOSÉ, I.C.; FERREIRA, F.A.; SEDIYAMA, C.S. Simulação da soja geneticamente modificada tolerante ao glifosato por meio do cultivo de explantes. Revista Brasileira de Fisiologia Vegetal, Campinas v.11, n.1, p.13-20, 1999.

TILLMANN, M.A.A.; WEST, S.H. Identification of genetically modified soybean (Glycine $\max$ L. Merr.) seeds resistant to glyphosate. Scientia Agricola, Piracicaba, v.61, n.3, p.336-341, 2004.

TORRES, A.C.; NASCIMENTO, W.M.; PAIVA, S.A.V.; ARAGÃO, F.A.S. Bioassay for detection of transgenic soybean seeds tolerant to glyphosate. Pesquisa Agropecuária Brasileira, Brasília, v.38, n.9, p.1053-1057, 2003. 